\title{
RELEVANSI KURIKULUM PRODI PENDIDIKAN TEKNIK MESIN FKIP UNIVERSITAS PALANGKA RAYA DENGAN KOMPETENSI GURU PEMULA SMK
}

\author{
I Made Supatra \\ FKIP Universitas Palangka Raya \\ i.made_supatra@yahoo.com \\ Soeharto \\ Fakultas Teknik Universitas Negeri Yogyakarta \\ hart_harto@yahoo.co.id \\ Abstrak
}

\begin{abstract}
Tujuan dari penelitian ini adalah untuk mengetahui gambaran relevansi kurikulum Program Studi Pendidikan Teknik Mesin FKIP Universitas Palangka Raya dengan kompetensi guru pemula SMK, berdasarkan tinjauan terhadap profil kurikulum dan profil kompetensi mahasiswa calon guru pemula SMK. Penelitian ini merupakan penelitian deskriptif dengan menggunakan The Explanatory Sequential Design. Informasi data penelitian diperoleh dari populasi 18 orang dosen dan dari populasi 24 orang mahasiswa yang melaksanakan PPL II. Hasil penelitian menunjukkan bahwa kurikulum Program Studi Pendidikan Teknik Mesin FKIP Universitas Palangka Raya relevan dengan kompetensi guru pemula SMK dengan persentase sebesar 72,96\%. Kompetensi yang dimiliki oleh mahasiswa PPL II relevan dengan kompetensi guru pemula SMK dengan persentase sebesar 63,64\%. Program Studi Pendidikan Teknik Mesin FKIP Universitas Palangka Raya belum menetapkan standar kompetensi lulusan untuk konsentrasi bidang otomotif. Terdapat empat pola hubungan antara materi kurikulum Program Studi Pendidikan Teknik Mesin FKIP Universitas Palangka Raya dengan Standar Kompetensi Guru Pemula SMK. Mahasiswa PPL II belum memiliki kompetensi secara utuh sebagai calon guru pemula SMK, dan belum mampu menciptakan atsmosfer belajar yang kondusif dalam proses pembelajaran di SMK.
\end{abstract}

Kata kunci: relevansi, kurikulum, kompetensi, guru pemula SMK

\section{THE RELEVANCE OF CURRICULUM OF MECHANICAL ENGINEERING EDUCATION PROGRAM OF THE FACULTY OF TEACHING AND EDUCATIONAL SCIENCES, PALANGKARAYA UNIVERSITY, WITH THE VET NOVICE TEACHERS' COMPETENCIES}

\begin{abstract}
The aim of this study was to determine the description of the relevance of the curriculum of Mechanical Engineering Education Program, Faculty of Teaching and Educational Sciences, Palangkaraya University, with the VET novice teachers' competencies based on the review of the curriculum profiles and the competency profiles of the VET novice teachers. This study was a descriptive study with the explanatory sequential design. This study was conducted to the curriculum of Mechanical Engineering Education Program, Faculty of Teaching and Educational Sciences, Palangkaraya University. The information of the research data was obtained from the population of 18 lecturers and the population of 24 students who performed PPL II. The results show that the curriculum of Mechanical Engineering Education Program of the Faculty of Teaching and Educational Sciences, Palangkaraya University is relevant with the VET novice teachers' competencies with the percentage of 72.96\%. The competencies possessed by the PPL II students are relevant with the VET novice teachers' competencies with the percentage of $63.64 \%$. The Mechanical Engineering Education Program, Faculty of Teaching and Educational Sciences, Palangkaraya University has not set competency standards for the concentration of automotive expertise. There are four patterns of relationship between curriculum materials of The Mechanical Engineering Education Program, Faculty of Teaching and Educational Sciences, Palangkaraya University with the VET novice teacher competency standards. The PPL II Students are not yet fully competent as VET novice teachers, and has not been able to create a conducive learning atsmosfer in the process of learning in VET.
\end{abstract}

Keywords: relevance, curriculum, competencies, VET novice teachers. 


\section{PENDAHULUAN}

Program Studi PTM FKIP UNPAR adalah salah satu LPTK PGSMK di bidang teknologi dan rekayasa yang berperan mempersiapkan calon guru untuk mampu mengajar di SMK bidang keahlian teknik mesin. Program Studi PTM FKIP UNPAR merupakan LPTK PGSMK jenjang S-1 yang belum lama berdiri, penerimaan mahasiswa angkatan pertama pada tahun ajaran 2004/2005. Visi yang diemban adalah menjadi program studi yang dapat menghasilkan sumber daya manusia bermoral Pancasila, bermutu, berkarakter, berdaya saing tinggi dengan penekanan menghasilkan guru profesional di bidang pendidikan teknik mesin. Tujuan yang ditetapkan yaitu menghasilkan lulusan/guru profesional di bidang pendidikan teknik mesin yang bermoral Pancasila, bermutu, berkarakter, dan berdaya saing tinggi.

Kompetensi guru SMK bidang teknik mesin merupakan kemampuan mengkoordinasikan unsur-unsur potensi, pengetahuan dan keterampilan di bidang teknik mesin, sikap dan nilai yang dimilikinya, yang dapat diwujudkan dalam bentuk tindakan atau kinerja pada proses pembelajaran yaitu proses mengembangkan potensi dan memfasilitasi kebutuhan belajar siswa di SMK bidang teknik mesin. Devore (1980,p.34) menyatakan "the study of technology is a study of the relation of skill - the behavior associated with the creating, making, and using of tools - to human action". Bahwasanya pendidikan di bidang teknologi erat kaitannya dengan proses pembentukan keterampilan dan perilaku yang berkaitan dengan menciptakan, membuat, dan menggunakan alat-alat teknologi.

European Union Programme For Croatia (2008,p.13) menyatakan "It is essential to further develop both vocational and educational skills of VET teachers, so that they could apply the new methodologies in their work with students". Dengan demikian guru akan mampu menunjukkan kinerjanya dalam bentuk penguasaan substansi kajian bidang kejuruan secara mendalam, pelaksanaan pembelajaran yang mendidik di SMK, kepribadian, komitmen dan perhatian terhadap perkembangan peserta didik di SMK, dan kemampuan untuk meningkatkan kompetensi peserta didik di SMK melalui penggalian informasi dari berbagai sumber dan melakukan kajian penelitian sebagai antisipasi perkembangan IPTEK.

Terkait dengan beberapa pernyataan tersebut, perencanaan kurikulum Program Studi PTM FKIP UNPAR seharusnya direncanakan dan dikembangkan dengan mempertimbangkan kebutuhan kompetensi guru pemula SMK di bidang teknik mesin, sehingga dapat menjawab hal-hal yang terkait dengan tujuan untuk menghasilkan calon guru yang mampu mengajar di SMK bidang teknik mesin.

Salah satu landasan pengembangan kurikulum LPTK untuk dapat menghasilkan guru professional yaitu Undang-Undang No.14 Tahun 2005 tentang Guru dan Dosen yang menegaskan bahwa "guru adalah tenaga profesional dengan tugas utama mendidik, mengajar, membimbing, mengarahkan, melatih, menilai, dan mengevaluasi peserta didik". Profesional dimaksud adalah merujuk kepada pekerjaan atau kegiatan yang dilakukan oleh seseorang dan menjadi sumber penghasilan kehidupan yang memerlukan keahlian, kemahiran, atau kecakapan yang memenuhi standar mutu atau norma tertentu serta memerlukan pendidikan profesi.

Terkait dengan pernyataan mengenai standar mutu, Piskurich (2006,p.118) menyatakan "Standards are important because they form the basis for trainee evaluation. ... Standards are a key part of every objective". Berdasarkan pemahaman tentang kompetensi yang dijelaskan berdasarkan atribut kompetensi, dapat dilakukan penentuan kompetensi dengan pendekatan berbasis kinerja, yang mengasumsikan bahwa kompetensi dapat disimpulkan dari kinerja yang ditunjukkan pada standar yang dapat diterima yang telah ditetapkan di tempat kerja, Gonczi(1993) dalam Project Management Institute (2001,pp.1-2).

Menurut standar kompetensi guru pemula sekolah menengah kejuruan, Diknas (2004, pp.12-14) bahwa lingkup kompetensi guru pemula SMK dikelompokkan kedalam empat rumpun, yaitu: (1) penguasaan bidang studi kejuruan; (2) pemahaman terhadap peserta didik di SMK; (3) penguasaan pembelajaran 
yang mendidik; dan (4) pengembangan kepribadian dan keprofesionalan.

Untuk mampu mengajar di SMK bidang keahlian teknik mesin, calon guru SMK perlu dibekali dengan penguasaan bidang studinya secara mendalam, yang meliputi: penguasaan substansi bidang studi; kemampuan mengaitkan dan mengaplikasikan bidang studi dan materi kurikulum bidang studi yang berlaku sesuai dengan konteks pendidikan di bidang studinya atau lingkungan; kemampuan mengembangkan konsep ilmu/teknologi di bidang studinya; penguasaan terhadap struktur dan materi kurikulum/diklat; kemampuan menyesuaikan materi keilmuan dengan perkembangan siswa di SMK; kemampuan merencanakan dan membimbing keselamatan dan kesehatan peserta didik dalam tempat kerja/unit produksi/ laboratorium; dan kemampuan mengelola tempat kerja/unit produksi/laboratorium.

Untuk dapat memahami dan mengembangkan potensi peserta didik di SMK, calon guru SMK perlu dibekali dengan: kemampuan mengidentifikasi potensi peserta didik di SMK yang perlu dikembangkan; penguasaan terhadap karakteristik potensi peserta didik di SMK; kemampuan untuk mengenal dan memanfaatkan lingkungan peserta didik di SMK; penguasaan terhadap cara belajar peserta didik di SMK; kemampuan bersikap dan berperilaku empati terhadap peserta didik; dan membimbing pengembangan karir peserta didik di SMK.

Untuk dapatmelaksanakan dan menyelenggarakan pembelajaran yang mendidik, calon guru SMK perlu dibekali dengan: kemampuan merencanakan dan merancang pembelajaran yang mendidik; penguasaan terhadap pendekatan, metode dan media pembelajaran; pemahaman terhadap prinsip dan prosedur asesmen proses dan hasil belajar peserta didik di SMK untuk mendukung merencanakan dan melaksanakan asesmen proses dan hasil belajar serta memanfaatkan hasil asesmen.

Untuk mendukung pengembangan kepribadian dan keprofesionalan sebagai calon guru SMK, seorang calon guru SMK perlu dibekali dengan: kemampuan menyesuaikan diri dengan lingkungan kerja di SMK; kemampuan menilai kinerjanya sendiri; kemampuan bekerja secara mandiri dan bekerja sama dengan orang lain; kemampuan mencari sumber-sumber baru dalam bidang studinya; pemahaman terhadap pentingnya komitment terhadap profesi dan tugas professional; kemampuan berkomunikasi dengan teman sejawat dan peserta didik; dan kemampuan untuk selalu meningkatkan diri dalam kinerja profesinya sebagai seorang guru SMK nantinya.

Perencanaan kurikulum sebagai tujuan untuk menghasilkan rencana belajar-mengajar yang efektif setidaknya mempertimbangkan lima komponen utama yang meliputi: (1) tujuan pembelajaran atau hasil dari rencana yang diusulkan; (2) isi/muatan berupa fakta-fakta penting, prinsip, konsep, dan pemahaman yang berkaitan dengan pengorganisasian dan tujuan; (3) kegiatan-kegiatan yang dapat digunakan untuk mencapai tujuan; (4) sumber daya yang mungkin digunakan untuk mengatasi tujuan; dan (5) alat ukur, atau sarana untuk menentukan apakah dan untuk apa tujuan yang direncanakan telah dicapai, Beane (1986, p.68)

Hasil analisis Gibson \& Mitchell (2005, p.165) menunjukkan bahwa ada tujuh komponen umum diseluruh model pengembangan dan pendekatan kurikulum yang sangat efektif, yaitu meliputi: (1) Philosophy, pernyataan tentang nilai-nilai dasar pendidikan dan keyakinan; (2) Environment, perencanaan lingkungan secara eksplisit; (3) Interpersonal inter-actions, fokus pada interaksi interpersonal yang memfasilitasi belajar yang optimal; (4) Curriculum, rencana kurikulum sesuai dengan tahapan perkembangan; (5) Instruction, strategi instruksional yang berhasil menantang kebutuhan individu siswa belajar; (6) Assessment, penilaian siswa yang sistematis dengan menggunakan berbagai metode; dan (7) Research, penelitian yang memberikan pertanggungjawaban atas pendekatan dan alasan penggunaannya.

Menurut Winecoff (1989,pp.3-4) dua komponen utama dalam proses pengembangan kurikulum di pendidikan tinggi yaitu: (1) pedoman kurikulum (tingkat makro) yang meliputi pengaturan, silabus, dan evaluasi 
untuk menentukan secara umum apa yang akan diajarkan, kepada siapa, mengapa, dalam rangka apa dan bagaimana urutannya; dan (2) panduan instruksional (tingkat mikro) yang didasarkan pada silabus untuk setiap pembelajaran, untuk menentukan secara khusus tujuan pembelajaran, modus instruksional, dengan apa (sumber daya belajar/mengajar), dan seberapa baik (evaluasi).

Penetapanjenis kompetensi sebagaistandar kompetensi lulusan menjadi ukuran terhadap kompetensi lulusan dan kualifikasi kemampuan lulusan yang mencakup sikap, pengetahuan, dan keterampilan yang akan dicapai oleh calon guru SMK setelah menyelesaikan proses pembelajaran di Program Studi PTM FKIP UNPAR. Berdasarkan pemahaman tentang kompetensi yang dijelaskan berdasarkan atribut kompetensi, dapat dilakukan penentuan kompetensi dengan pendekatan berbasis kinerja, yang mengasumsikan bahwa kompetensi dapat disimpulkan dari kinerja yang ditunjukkan pada standar yang dapat diterima seperti yang ditetapkan.

Untuk mewujudkan pencapain konpetensi tersebut, maka kurikulum diimplementasikan dalam bentuk proses pembelajaran yaitu proses interaksi dan interrelasi antar berbagai komponen yang meliputi dosen, mahasiswa, tujuan pembelajaran, materi pembelajaran, dan metode atau strategi pembelajaran. Dalam proses interaksi tersebut mahasiswa mengalami proses perubahan ranah kognitif, ranah afektif, ranah psikomotorik, dan ranah kooperatif. Dalam hal ini kepiawaian dosen dalam menjalankan strategi dan proses pembelajaran akan sangat menentukan tercapainya tujuan pembelajaran sebagai pengikat segala aktivitas dosen dan mahasiswa. Selain itu keberadaan prasarana dan sarana menjadi suatu hal yang vital, karena bagaimanapun tanpa prasarana dan sarana tidaklah mungkin dapat dilakukan proses pembelajaran di lembaga pendidikan kejuruan.

Suasana akademik merupakan kondisi yang harus mampu diciptakan untuk membuat proses pembelajaran berjalan sesuai dengan visi, misi, dan tujuannya. Suasana akademik yang kondusif akan tercermin dari proses interaksi antara dosen dan mahasiswa, antara sesama mahasiswa, maupun antara sesama dosen untuk mengoptimalkan proses pembelajaran. Suasana akademik yang kondusif juga dapat diwujudkan melalui interaksi akademik, kegiatan akademik, akses terhadap sumber belajar, kecukupan dan ketepatan sumber belajar, keikutsertaan mahasiswa dalam aktivitas kurikuler maupun ko-kurikuler dan ekstra-kurikuler, dan lain-lain.

Berdasarkan beberapa uraian di atas, kurikulum Program Studi PTM FKIP UNPAR sebagai suatu program pendidikan di LPTK PGSMK seharusnya direncanakan dan dikembangkan berdasarkan konsep atau kerangka teori yang jelas secara ilmiah sesuai dengan pendidikan di bidang teknik mesin. Perencanaan dan pengembangan kurikulum tersebut melalui kegiatan penelitian ataupun kegiatan praktik professional, dirancang dalam bentuk dokumen tertulis yang memuat tentang struktur organisasi, tujuan pendidikan, jenis kegiatan, keperluan bahan, keperluan alat-alat, dan alokasi waktu. Hasil dari perencanaan dan pengembangan kurikulum tersebut kemudian dilaksanakan dalam bentuk praktek pembelajaran sehingga diperoleh serangkaian hasil belajar yang diharapkan dari kurikulum sebagai suatu kegiatan, yaitu terjadinya perubahan perilaku dan perolehan calon guru SMK terhadap kemampuan untuk mengajar pada jenjang pendidikan menengah kejuruan bidang keahlian teknik mesin. Kemampuan tersebut meliputi penguasaan bidang studi pendidikan teknik mesin secara mendalam, pemahaman tentang peserta didik di SMK, penguasaan cara belajar yang mendidik di SMK, dan pengembangan kepribadian dan keprofesionalan sebagai seorang calon guru SMK.

Berdasarkan hasil observasi yang dilakukan, penyusunan kurikulum Program Studi PTM FKIP UNPAR belum melibatkan eksternal stakeholders, yang terlibat baru pihak internal program studi. Penentuan isi atau muatan kurikulum dilakukan dengan mengadopsi muatan kurikulum program studi sejenis yang dianggap mapan. Untuk itu, perlu dilakukan evaluasi dan tinjauan kurikulum yang digunakan Program Studi PTM FKIP UNPAR sehingga diketahui relevansinya terhadap 
kebutuhan SMK dan kebutuhan masyarakat (stakeholders). Relevansi kurikulum tersebut ditunjukkan dengan adanya kecocokan, keterpautan yang memberikan manfaat secara langsung dan ditentukan oleh argumen ilmiah atau menggunakan metode profesional, di mana kurikulum Program Studi PTM FKIP UNPAR dikatakan relevan dengan tugasnya untuk memberikan landasan kompetensi apabila dalam proses keterpautannya meningkatkan kemungkinan mencapai tujuan menghasilkan calon guru pemula SMK berkompeten, yang tersirat oleh kompetensi yang dimiliki oleh calon guru pemula SMK.

\section{METODE PENELITIAN}

\section{Jenis penelitian}

Penelitian ini merupakan penelitian deskriptif eksplanatif yang berusaha mendeskripsikan tentang relevansi kurikulum Program Studi PTM FKIP UNPAR dengan kompetensi calon guru pemula SMK, yang ditinjau dari profil kurikulum dan profil kompetensi yang dimiliki mahasiswa calon guru pemula SMK. Pendekatan yang digunakan dalam penelitian ini adalah pendekatan kuantitatif dan didukung dengan pendekatan kualitatif, dengan desain penelitian yang digunakan adalah the explanatory sequential design yang juga disebut sebagai desain penjelas. Menurut Creswell \& Clark (2011,p.71) the explanatory sequential design adalah desain penelitian di mana penelitian tahap pertama dengan melakukan fase kuantitatif kemudian menindaklanjuti hasil tertentu yang dianggap tak terduga dengan tahap kedua yaitu fase kualitatif. Fase kualitatif dilaksanakan untuk tujuan menjelaskan hasil awal secara lebih mendalam, sebagai fokus pada menjelaskan hasil seperti yang tercermin dalam nama desain.

\section{Tempat dan waktu penelitian}

Penelitian ini dilakukan di Program Studi Pendidikan Teknik Mesin FKIP Universitas Palangka Raya (UNPAR), dengan alamat Jalan Hendrik Timang Kampus UNPAR Tunjung Nyaho Palangka Raya Kalimantan Tengah
73112. Penelitian dilaksanakan pada Semester Genap tahun pelajaran 2012/2013. Prasurvei dilaksanakan dari tanggal 29 Agustus 2012 sampai dengan tanggal 5 September 2012. Pengumpulan data pada tahap kuantitatif dilakukan pada tanggal 18 dan 19 Februari 2013. Pengumpulan data pada tahap kualitatif dilakukan selama tiga bulan yaitu dari tanggal 01 Maret 2013 hingga 30 Mei 2013.

\section{Populasi dan sampel penelitian}

Metode pengambilan sampel yang digunakan dalam fase kuantitatif adalah purposive sampling. Untuk pengumpulan data tentang kompetensi yang dimiliki oleh calon guru pemula SMK, respondennya adalah populasi mahasiswa program studi PTM FKIP UNPAR yang sedang melaksanakan PPL II tahun ajaran 2012/2013 yang berjumlah 24 orang. Untuk pengumpulan data tentang profil kurikulum program studi PTM FKIP UNPAR, respondennya adalah populasi dosen program studi PTM FKIP UNPAR yang berjumlah 18 orang. Pemilihan populasi mahasiswa PPL II dengan pertimbangan bahwa mahasiswa yang sedang melaksanakan PPL II mengetahui dan mengalami proses pendidikan di program studi PTM FKIP UNPAR, dan telah memenuhi kriteria SKS minimum untuk melaksanakan PPL II. Pemilihan Populasi dosen sebagai responden dengan pertimbangan bahwa seluruh dosen turut merencanakan dan melaksanakan kurikulum program studi PTM FKIP UNPAR.

\section{Teknik pengumpulan data}

Teknik pengumpulan data yang digunakan dalam penelitian ini disesuaikan dengan kebutuhan dan sifat data yang akan dihimpun berdasarkan fase kuantitatif dan fase kualitatif. Pengumpulan data pada fase kuantitatif dilakukan melalui penyebaran instrumen dengan jenis angket tertutup. Data yang dikumpulkan melalui angket tertutup adalah data tentang profil kompetensi calon guru pemula SMK, dan data tentang profil kurikulum program studi PTM FKIP UNPAR. Teknik pengumpulan data yang digunakan pada fase kualitatif meliputi observasi langsung, wawancara mendalam (in-depth interview), dan dokumentasi. Dalam pelaksanaan in-depth 
Tabel 1. Distribusi Frekuensi Profil Kurikulum

\begin{tabular}{ccccccc}
\hline No Kelas & Kelas Interval & $\boldsymbol{f i}$ & $\boldsymbol{X i}$ & $\boldsymbol{f i} \%$ & $\boldsymbol{f i} \mathbf{~ k u m}$ & $\boldsymbol{f i} \mathbf{~ k u m} \%$ \\
\hline 1 & $390,0-419,1$ & 5 & 404,6 & 28 & 5 & 28 \\
2 & $419,2-448,3$ & 3 & 433,8 & 17 & 8 & 44 \\
3 & $448,4-477,5$ & 4 & 463,0 & 22 & 12 & 67 \\
4 & $477,6-506,7$ & 4 & 492,2 & 22 & 16 & 89 \\
5 & $506,8-535,9$ & 0 & 521,4 & 0 & 16 & 89 \\
6 & $536,0-565,1$ & 2 & 550,6 & 11 & 18 & 100 \\
\hline Jumlah & & 18 & & 100 & &
\end{tabular}

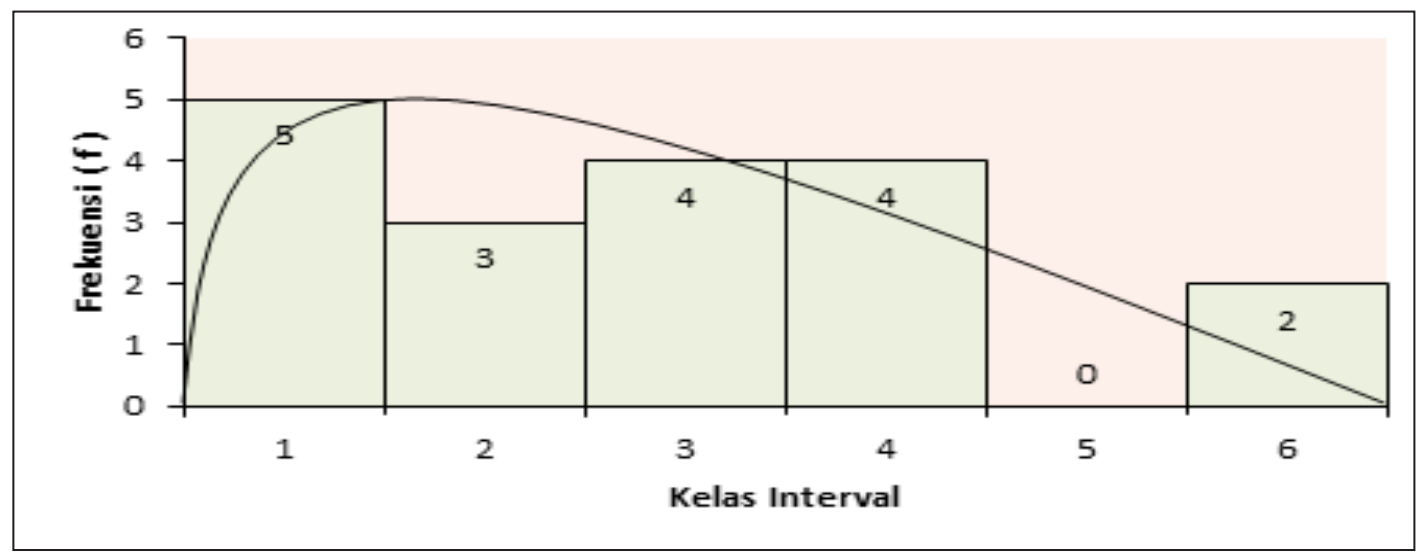

Gambar 1. Distribusi Frekuensi Skor Tiap Interval Pernyataan tentang Profil Kurikulum

interview peneliti menggunakan pendekatan terbuka, yaitu subjek diberikan cakupan topik untuk dibicarakan, tapi subjek bebas untuk memilih topik mana yang mau dibicarakan; dan subjek diberikan daftar pertanyaan panduan, tetapi bebas untuk mengadaptasikannya untuk mendapatkan informasi yang dibutuhkan.

\section{Teknik analisis data}

Analisis data kuantitatif dilakukan setelah angket yang disebar terkumpul kembali. Teknik analisis yang digunakan adalah analisis data statistik deskriptif. Tujuan dari analisis ini adalah untuk mendeskripsikan sejauh mana relevansi kurikulum program studi PTM FKIP UNPAR dengan kompetensi guru pemula SMK. Setelah fase kuantitatif selesai, selanjutnya dilakukan identifikasi terhadap temuan kuantitatif sebagai dasar untuk melakukan follow-up melalui fase kualitatif. Identifikasi dilakukan dengan melihat dan mengamati pola hubungan dengan mempertimbangkan bentuk atau pola data hasil analisis, meliputi hasil yang signifikan, bermakna, atau outlier.
Jenis analisis yang digunakan pada fase kualitatif adalah interactive model (Model Miles dan Huberman) yang meliputi kegiatan reduksi data, penyajian data, dan membuat kesimpulan/verifikasi terhadap data yang terkumpul. Interpretasi temuan kualitatif terhadap temuan kuantitatif dilakukan setelah fase kualitatif selesai. Interpretasi dilakukan untuk melakukan penafsirkan bagaimana temuan kualitatif membantu menjelaskan hasil yang tak terduga dari temuan kuantitatif.

\section{HASIL PENELITIAN DAN PEMBAHASAN}

\section{Profil kurikulum Program Studi PTM FKIP UNPAR}

Profil kurikulum dapat dilihat pada tabel 1 yang meliputi lima komponen, dengan jumlah total butir pernyataan untuk profil kurikulum adalah 126 butir, skor ideal tiap responden adalah 630, dan skor ideal profil kurikulum adalah 11.340. Dari deskripsi data diketahui 
Tabel 2. Distribusi Frekuensi Komponen Tujuan

\begin{tabular}{ccccccc}
\hline No Kelas & Kelas Interval & $\boldsymbol{f i}$ & $\boldsymbol{X i}$ & $\boldsymbol{f i} \%$ & $\boldsymbol{f i} \mathbf{~ k u m}$ & $\boldsymbol{f i} \mathbf{~ k u m} \%$ \\
\hline 1 & $64-70$ & 3 & 67,0 & 17 & 3 & 17 \\
2 & $71-77$ & 6 & 74,0 & 33 & 9 & 50 \\
3 & $78-84$ & 4 & 81,0 & 22 & 13 & 72 \\
4 & $85-91$ & 1 & 88,0 & 6 & 14 & 78 \\
5 & $92-98$ & 3 & 95,0 & 17 & 17 & 94 \\
6 & $99-105$ & 1 & 102,0 & 6 & 18 & 100 \\
\hline Jumlah & & 18 & & 100 & &
\end{tabular}

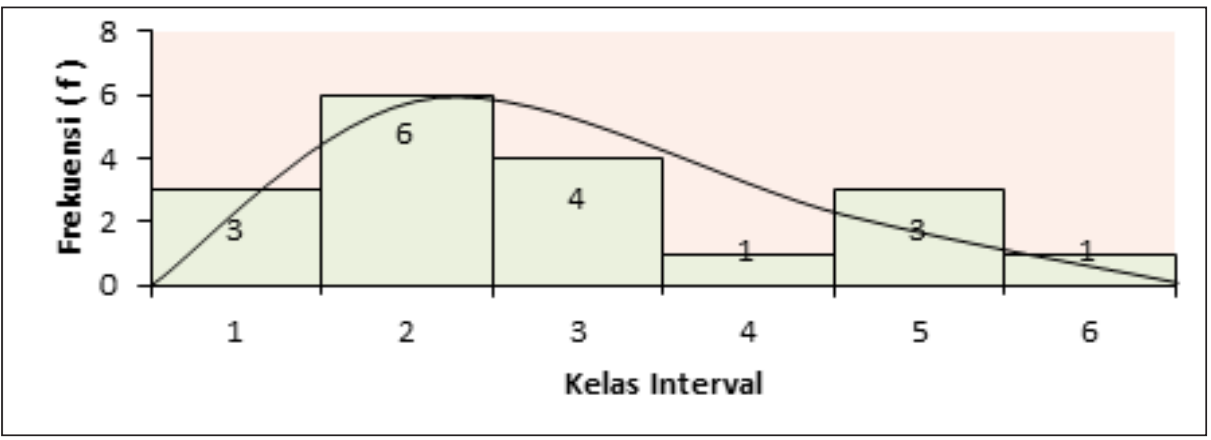

Gambar 2. Distribusi Frekuensi Skor Tiap Interval Pernyataan tentang Komponen Tujuan

bahwa skor total yang diperoleh untuk profil kurikulum yaitu 8.274 , di mana skor untuk tiap responden yang terbesar adalah 564 dan terkecil adalah 396.

Secara umum berdasarkan kajian secara kuantitatif, ditemukan bahwa relevansi kurikulum program studi PTM FKIP UNPAR dengan kebutuhan kompetensi guru pemula SMK Bidang Teknik Mesin termasuk dalam kategori relevan yaitu dengan nilai $72,96 \%$. Ditinjau dari profil kurikulum berdasarkan seluruh komponen kurikulum, kondisinya masih di bawah rerata dengan Me $(458,08)$ $>$ Md $(455,63)>$ Mo $(410,81)$ dan koevisien variasi data 0,1002 .

\section{Komponen tujuan}

Komponen tujuan dapat dilihat pada tabel 2 yang meliputi tiga aspek, dengan jumlah pernyataan 22 butir, skor ideal tiap responden 110 , dan skor ideal untuk komponen tujuan 1980. Dari deskripsi data diketahui bahwa skor total yang diperoleh untuk aspek komponen tujuan yaitu 1.453, di mana skor untuk tiap responden yang terbesar adalah 104 dan terkecil adalah 64.
Berdasarkan kajian secara kuantitatif, relevansi tujuan kurikulum Program Studi PTM FKIP UNPAR dengan kebutuhan kompetensi guru pemula SMK Bidang Teknik Mesin termasuk dalam kategori relevan dengan nilai $73,38 \%$. Ditinjau dari seluruh aspek profil komponen tujuan, kondisinya masih di bawah rerata dengan Me 80,22> Md 76,95>Mo 75,15 dan koevisien variasi data 0,1297. Melalui hasil kajian kualitatif dapat dijelaskan lebih lanjut gambaran profil komponen tujuan. Visi misi Program Studi FKIP UNPAR secara umum memiliki keterkaitan dengan visi misi FKIP UNPAR dan visi misi UNPAR, namun secara khusus belum ada misi Program Studi PTM FKIP UNPAR yang terkait dengan pengembangan pendidikan teknologi mesin pada daerah rawa gambut sesuai dengan misi UNPAR. Penetapan tujuan dan sasaran Program Studi PTM FKIP UNPAR mengacu pada visi misi yang telah ditetapkan. Penetapan SKL Program Studi PTM belum melalui proses analisis kebutuhan lulusan, stakeholders yang terlibat dalam perumusan komponen tujuan baru pihak internal program studi. Dari dua konsentrasi bidang keahlian yang diselenggarakan baru konsentrasi bidang 
Tabel 3. Distribusi Frekuensi Komponen Isi/Materi

\begin{tabular}{ccccccc}
\hline No Kelas & Kelas Interval & $\boldsymbol{f i}$ & $\boldsymbol{X i}$ & $\boldsymbol{f i} \%$ & $\boldsymbol{f i} \mathbf{~ k u m}$ & $\boldsymbol{f i \mathbf { k u m } \%}$ \\
\hline 1 & $84-91$ & 1 & 87,5 & 6 & 1 & 6 \\
2 & $92-99$ & 8 & 95,5 & 44 & 9 & 50 \\
3 & $100-107$ & 2 & 103,5 & 11 & 11 & 61 \\
4 & $108-115$ & 5 & 111,5 & 28 & 16 & 89 \\
5 & $116-123$ & 1 & 119,5 & 6 & 17 & 94 \\
6 & $124-131$ & 1 & 127,5 & 6 & 18 & 100 \\
\hline
\end{tabular}

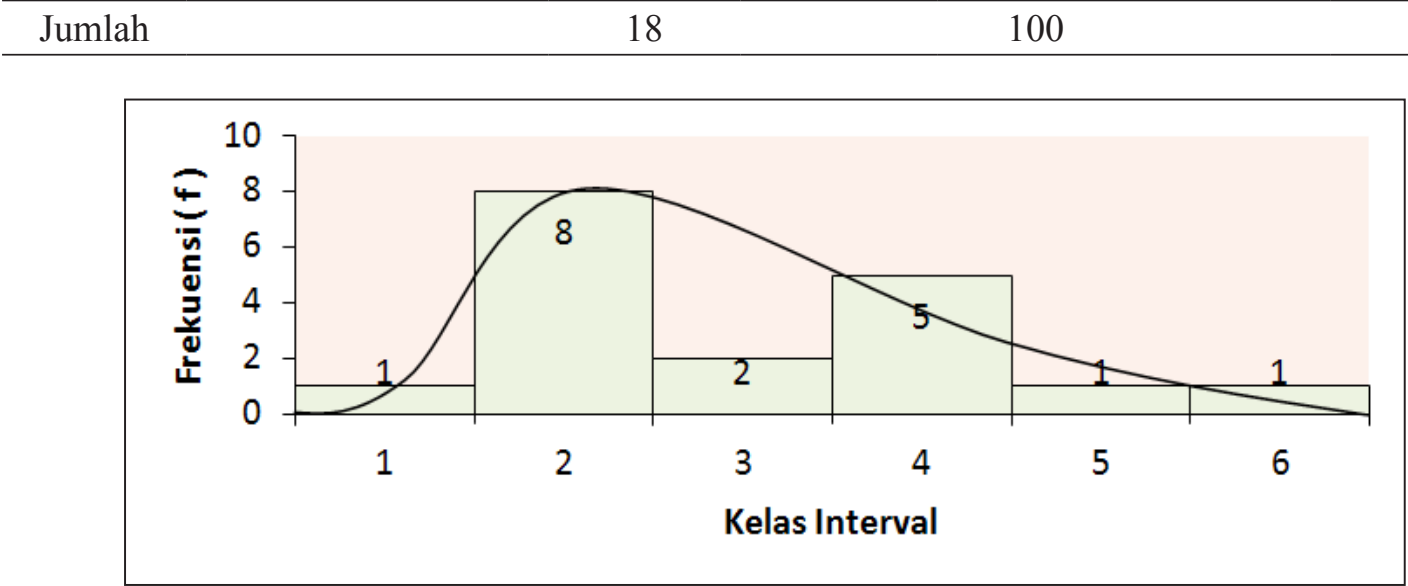

Gambar 3. Distribusi Frekuensi Skor Tiap Interval Pernyataan tentang Komponen Isi/Materi

mesin produksi yang telah dilengkapi dengan dokumen SKL, sedangkan konsentrasi bidang otomotif belum dilengkapi dengan dokumen SKL.

\section{Komponen isi/materi}

Komponen isi/materi dapat dilihat pada tabel 3, meliputi lima aspek dengan jumlah pernyataan 28 butir, skor ideal tiap responden 140, dan skor ideal untuk komponen isi/materi 2.520. Dari deskripsi data diketahui bahwa skor total yang diperoleh untuk aspek komponen isi/materi yaitu 1.860 , dimana skor untuk tiap responden yang terbesar adalah 130 dan terkecil adalah 84 .

Berdasarkan kajian secara kuantitatif, relevansi isi/materi kurikulum Program Studi PTM FKIP UNPAR dengan kompetensi dasar yang harus dikuasai siswa sebagaimana tercantum pada kurikulum SMK Bidang Teknik Mesin termasuk dalam kategori relevan dengan nilai $73,81 \%$. Ditinjau dari seluruh aspek profil komponen isi/materi, kondisinya masih di bawah rerata dengan Me103,50>Md 98,95>Mo 96,26 dan koevisien variasi data 0,0998 .
Melalui hasil kajian kualitatif dapat dijelaskan gambaran profil komponen isi/materi bahwa perencanaan dan penetapan isi/ materi kurikulum mengacu pada Kepmen No. 232/U/2000. Materi kajian sebagai rangkaian materi kurikulum Program Studi PTM FKIP UNPAR diadopsi dari institusi sejenis yang dianggap sudah mapan, dan penyusunan struktur materi kurikulum belum mempertimbangkan karakteristik keterkaitan antar kompetensi yang terkandung dalam materi kajian.

Materi kajian pada kurikulum Program Studi FKIP UNPAR tersusun dari: (1) sejumlah 23 matakuliah pada kurikulum konsentrasi bidang mesin produksi dan 13 matakuliah pada kurikulum konsentrasi bidang otomotif dengan pola hubungan satu materi kajian (matakuliah) bertujuan untuk mencapai lebih dari empat kompetensi; (2) sejumlah 44 indikator kompetnsi SKGP SMK konsentrasi bidang mesin produksi dan 42 indikator kompetensi SKGP SMK konsentrasi bidang otomotif dengan pola hubungan satu kompetensi dibentuk melalui beberapa matakuliah yang berbeda; (3) terdapat juga pola hubungan dimana beberapa matakuliah yang berbeda memiliki keterkai- 
Tabel 4. Distribusi Frekuensi Komponen Prasarana Sarana

\begin{tabular}{ccccccc}
\hline No Kelas & Kelas Interval & $\boldsymbol{f i}$ & $\boldsymbol{X i}$ & $\boldsymbol{f i} \%$ & $\boldsymbol{f i} \mathbf{~ k u m}$ & $\boldsymbol{f i \mathbf { ~ k u m } \%}$ \\
\hline 1 & $25-32$ & 2 & 28,5 & 11 & 2 & 11 \\
2 & $33-40$ & 4 & 36,5 & 22 & 6 & 33 \\
3 & $41-48$ & 2 & 44,5 & 11 & 8 & 44 \\
4 & $49-56$ & 7 & 52,5 & 39 & 15 & 83 \\
5 & $57-64$ & 2 & 60,5 & 11 & 17 & 94 \\
6 & $65-72$ & 1 & 68,5 & 6 & 18 & 100 \\
\hline Jumlah & & 18 & & 100 & &
\end{tabular}

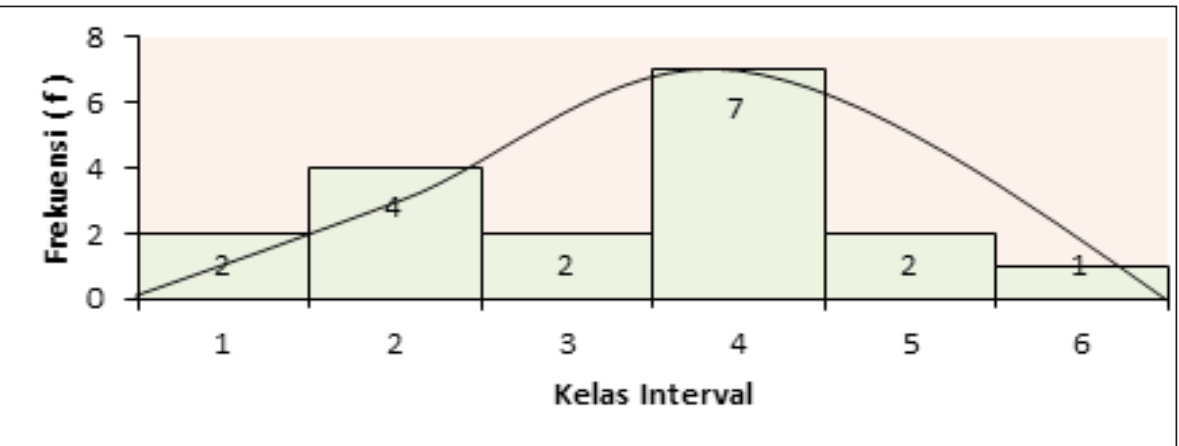

Gambar 4. Distribusi Frekuensi Skor Tiap Interval Pernyataan tentang Komponen Prasarana Sarana

tan untuk membentuk beberapa kompetensi; dan (4) sejumlah 18 matakuliah pada kurikulum konsentrasi bidang mesin produksi dan 29 matakuliah pada kurikulum konsentrasi bidang otomotif dengan pola hubungan satu matakuliah bertujuan untuk membentuk satu kompetensi.

Masing-masing sejumlah 6 matakuliah pada materi kurikulum konsentrasi bidang mesin produksi konsentrasi bidang otomotif yang tujuan pencapaian kompetensinya tidak terkait langsung dengan SKGP SMK bidang keahlian mesin produksi dan bidang keahlian otomotif. Sejumlah 2 indikator kompetensi SKGP SMK bidang keahlian mesin produksi dan 4 indikator kompetensi SKGP SMK bidang keahlian otomotif tidak terkandung dalam rangkain materi kurikulum Program Studi PTM FKIP UNPAR.

\section{Komponen Prasarana sarana}

Komponen prasarana sarana yang dapat dilihat pada tabel 4 meliputi tiga aspek, dengan jumlah pernyataan 15 butir, skor ideal tiap responden 75, dan skor ideal untuk komponen prasarana sarana 1.350. Dari deskripsi data diketahui bahwa skor total yang diperoleh untuk aspek komponen prasarana sarana yaitu 834, di mana skor untuk tiap responden yang terbesar adalah 70 dan terkecil adalah 27 .

Berdasarkan kajian secara kuantitatif, relevansi prasarana sarana di Program Studi PTM FKIP UNPAR mendukung proses untuk menghasilkan calon guru pemula SMK Bidang Teknik Mesin termasuk dalam kategori relevan dengan nilai $61,78 \%$. Ditinjau dari seluruh aspek profil komponen prasarana sarana, kondisinya di atas rerata dengan $\mathrm{Me} 47,17<\mathrm{Md}$ $49,95<$ Mo 52,95 dan koevisien variasi data 0,2331. Melalui hasil kajian kualitatif, lebih lanjut dapat dijelaskan gambaran profil komponen prasarana sarana. Untuk mendukung pelaksanaan kurikulum Program Studi PTM FKIP UNPAR, tersedia prasarana sarana yang meliputi fasilitas fisik dan umum, fasilitas pembelajaran, dan sumber belajar utama. Secara keseluruhan kondisinya masih belum memadai terutama untuk sumber belajar utama (perpustakaan) dan sarana pendukung kegiatan praktikum.

\section{Komponen proses}

Komponen proses yang dapat dilihat pada tabel 5 meliputi tiga aspek, dengan jumlah per- 
Tabel 5. Distribusi Frekuensi Komponen Proses

\begin{tabular}{ccccccc}
\hline No Kelas & Kelas Interval & $\boldsymbol{f i}$ & $\boldsymbol{X i}$ & $\boldsymbol{f i} \%$ & $\boldsymbol{f i} \mathbf{~ k u m}$ & $\boldsymbol{f i \mathbf { ~ k u m } \%}$ \\
\hline 1 & $114-122$ & 1 & 118,0 & 5,56 & 1 & 5,56 \\
2 & $123-131$ & 2 & 127,0 & 11,11 & 3 & 16,67 \\
3 & $132-140$ & 3 & 136,0 & 16,67 & 6 & 33,33 \\
4 & $141-149$ & 6 & 145,0 & 33,33 & 12 & 66,67 \\
5 & $150-158$ & 5 & 154,0 & 27,78 & 17 & 94,44 \\
6 & $159-167$ & 1 & 163,0 & 5,56 & 18 & 100,00 \\
\hline Jumlah & & 18 & & 100 & &
\end{tabular}

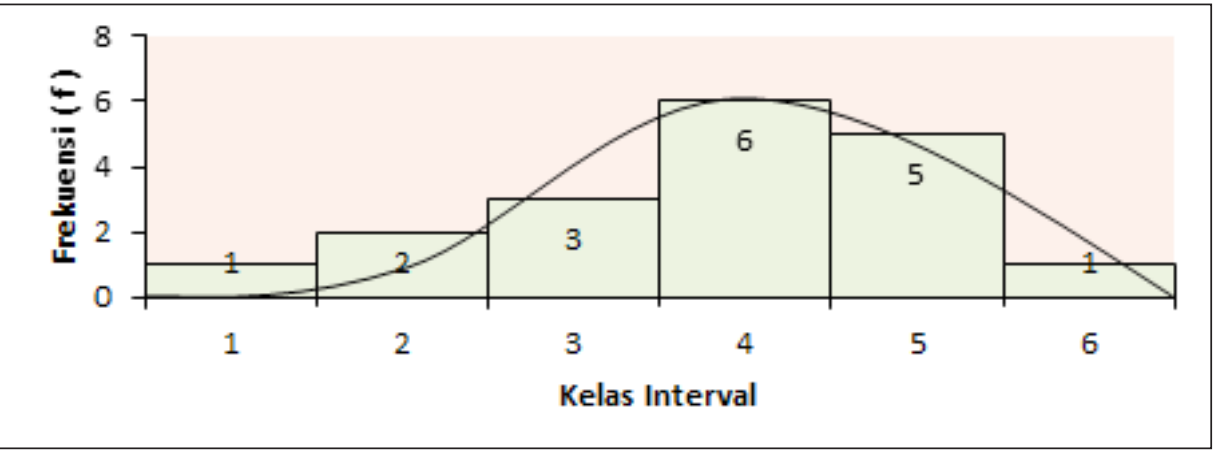

Gambar 5. Distribusi Frekuensi Skor Tiap Interval Pernyataan tentang Komponen Prosesa

nyataan 38 butir, skor ideal tiap responden 190, dan skor ideal untuk komponen proses 3.420 . Dari deskripsi data tersebut diketahui bahwa skor total yang diperoleh untuk aspek komponen proses yaitu 2.564 , di mana skor untuk tiap responden yang terbesar adalah 167 dan terkecil adalah 114.

Berdasarkan kajian secara kuantitatif, relevansi proses pelaksanaan kurikulum Program Studi PTM FKIP UNPAR dengan tujuan untuk menghasilkan calon guru pemula SMK Bidang Teknik Mesin termasuk dalam kategori relevan dengan nilai $74,97 \%$. Ditinjau dari seluruh aspek profil komponen proses, kondisinya sudah di atas rerata. dengan $\mathrm{Me} 143,50<\mathrm{Md}$ $144,95<$ Mo 147,70 dan koevisien variasi data 0,0789. Melalui hasil kajian kualitatif, lebih lanjut dapat dijelaskan gambaran profil komponen proses. Untuk mendukung pelaksanaan perkuliahan, seluruh matakuliah yang diselenggarakan memiliki silabus, namun capaian kompetensi untuk tiap matakuliah belum terdefenisi dengan jelas. Pelaksanaan kuliah praktikum belum sepenuhnya dapat dilaksanakan di Program Studi PTM FKIP UNPAR, beberapa pelaksanaan praktikum dilaksanakan di BLK
Kota Palangka Raya. Tenaga pengajar (dosen) untuk bidang keahlian otomotif masih belum memadai, beberapa perkuliahan pelaksanaannya dibantu oleh beberapa dosen yang memiliki keahlian pada rumpun yang sama. Pelaksanaan perkuliahan belum berorientasi pada student centered learning, secara umum perkuliahan masih dilaksanakan sepenuhnya dengan metode ceramah.

\section{Komponen evaluasi}

Komponen evaluasi yang terdapat pada tabel 6 meliputi tiga aspek, dengan jumlah pernyataan 23 butir, skor ideal tiap responden adalah 115, dan skor ideal untuk komponen evaluasi adalah 2.070. Dari deskripsi data tersebut diketahui bahwa skor total yang diperoleh untuk aspek komponen evaluasi yaitu 1.563 , di mana skor untuk tiap responden yang terbesar adalah 106 dan terkecil adalah 72 .

Berdasarkan kajian secara kuantitatif, relevansi sistem evaluasi di Program Studi PTM FKIP UNPAR dengan tujuan untuk menghasilkan calon guru pemula SMK di Bidang Teknik Mesin termasuk dalam kategori relevan dengan nilai $75,51 \%$. Ditinjau dari seluruh 
Tabel 6. Distribusi Frekuensi Komponen Evaluasi

\begin{tabular}{ccccccc}
\hline No Kelas & Kelas Interval & $\boldsymbol{f i}$ & $\boldsymbol{X i}$ & $\boldsymbol{f i} \%$ & $\boldsymbol{f i} \mathbf{~ k u m}$ & $\boldsymbol{f i} \mathbf{~ k u m} \%$ \\
\hline 1 & $72-77$ & 1 & 74,5 & 6 & 1 & 6 \\
2 & $78-83$ & 6 & 80,5 & 33 & 7 & 39 \\
3 & $84-89$ & 5 & 86,5 & 28 & 12 & 67 \\
4 & $90-95$ & 4 & 92,5 & 22 & 16 & 89 \\
5 & $96-101$ & 0 & 98,5 & 0 & 16 & 89 \\
6 & $102-107$ & 2 & 104,5 & 11 & 18 & 100 \\
\hline Jumlah & & 18 & & 100 & &
\end{tabular}

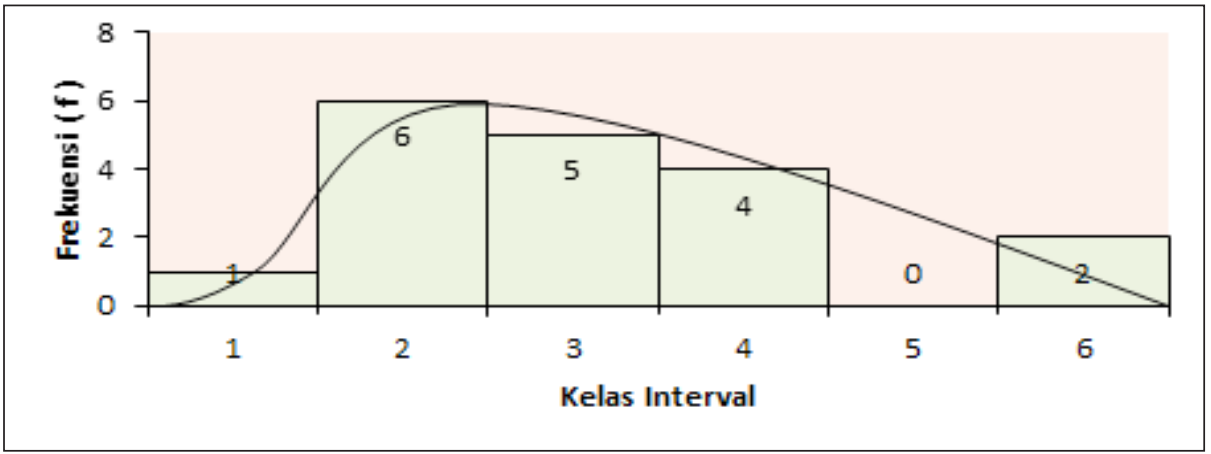

Gambar 6. Distribusi Frekuensi Skor Tiap Interval Pernyataan tentang Komponen Evaluasi

aspek profil komponen evaluasi, kondisinya masih di bawah rerata dengan $\mathrm{Me} 87,17>\mathrm{Md}$ $85,95>$ Mo 82,95 dan koevisien variasi data 0,0915. Melalui hasil kajian kualitatif, lebih lanjut dapat dijelaskan gambaran profil komponen evaluasi. Kegiatan evaluasi di program studi PTM FKIP UNPAR masih berfokus pada evaluasi hasil belajar mahasiswa, meliputi; evaluasi perkuliahan persemester, evaluasi kegiatan praktik lapangan, evaluasi tugas akhir mahasiswa. Evaluasi kurikulum masih merupakan kegiatan insidental di mana evaluasi baru dilaksanakan apabila dipandang perlu. Untuk evaluasi terhadap lulusan baru dilaksanakan dalam bentuk penelusuran keterserapannya di dunia kerja.

\section{Profil Kompetensi Calon Guru Pemula SMK}

Profil kompetensi calon guru pemula SMK yang dapat dilihat pada tabel 7 meliputi empat rumpun kompetensi dengan jumlah butir pernyataan sebanyak 118 butir, skor ideal tiap responden 1.180, dan skor ideal untuk profil kompetensi calon guru pemula SMK 28.320. Dari deskripsi data tersebut diketahui bahwa skor total yang diperoleh untuk Profil kompe- tensi calon guru pemula SMK yaitu 18.024, di mana skor untuk tiap responden yang terbesar adalah 951 dan terkecil adalah 571.

Berdasarkan kajian secara kuantitatif, relevansi kompetensi yang dimiliki Mahasiswa Program Studi PTM FKIP UNPAR yang sedang melaksanakan PPL II pada tahun ajaran 2012/2013, dengan kompetensi guru pemula SMK termasuk dalam kategori relevan yaitu dengan nilai 63,64\%. Ditinjau dari profil seluruh rumpun kompetensi guru pemula SMK, kondisinya masih di bawah rerata dengan $\mathrm{Me}$ $(753,22)>\operatorname{Md}(742,96)>$ Mo $(602,65)$ dan koevisien variasi data 0,1304 .

\section{Kompetensi Penguasaan Bidang Studi}

Rumpun kompetensi penguasaan bidang studi yang dapat dilihat pada tabel 8 meliputi tujuh aspek dengan jumlah pernyataan sebanyak 26 butir, skor ideal tiap responden 260, dan skor ideal untuk rumpun kompetensi penguasaan bidang studi 6.240. Dari deskripsi data tersebut diketahui bahwa skor total yang diperoleh untuk aspek kompetensi penguasaan bidang studi yaitu 4.008, di mana skor untuk tiap responden yang terbesar adalah 222 dan terkecil adalah 134. 
Tabel 7. Distribusi Frekuensi tentang Profil Kompetensi Calon Guru Pemula SMK

\begin{tabular}{ccccccc}
\hline No Kelas & Kelas Interval & $\boldsymbol{f i}$ & $\boldsymbol{X i}$ & $\boldsymbol{f i} \%$ & $\boldsymbol{f i} \mathbf{~ k u m}$ & $\boldsymbol{f i} \mathbf{~ k u m} \%$ \\
\hline 1 & $571,0-634,3$ & 3 & 602,7 & 13 & 3 & 13 \\
2 & $634,4-697,7$ & 4 & 666,1 & 17 & 7 & 29 \\
3 & $697,8-761,1$ & 7 & 729,5 & 29 & 14 & 58 \\
4 & $761,2-824,5$ & 5 & 792,9 & 21 & 19 & 79 \\
5 & $824,6-887,9$ & 1 & 856,3 & 4 & 20 & 83 \\
6 & $888,0-951,3$ & 4 & 919,7 & 17 & 24 & 100 \\
\hline Jumlah & & 18 & & 100 & &
\end{tabular}

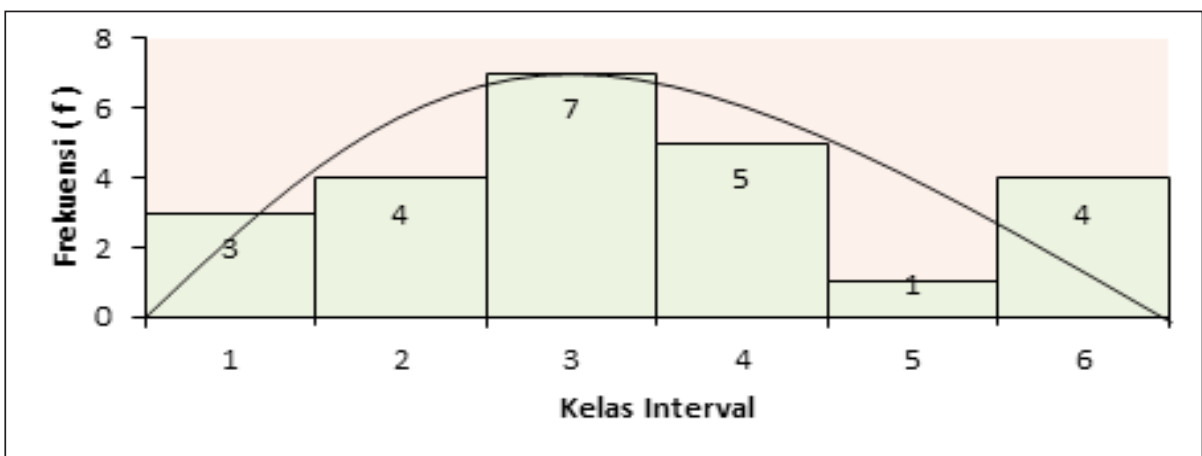

Gambar 7. Distribusi Frekuensi Skor Tiap Interval Pernyataan tentang Profil Kompetensi Calon Guru Pemula SMK

Tabel 8. Distribusi Frekuensi tentang Rumpun Kompetensi Penguasaan Bidang Studi

\begin{tabular}{ccccccc}
\hline No Kelas & Kelas Interval & $\boldsymbol{f i}$ & $\boldsymbol{X i}$ & $\boldsymbol{f i} \%$ & $\boldsymbol{f i} \mathbf{~ k u m}$ & $\boldsymbol{f i} \mathbf{~ k u m} \%$ \\
\hline 1 & $134-148$ & 5 & 141,0 & 21 & 5 & 21 \\
2 & $149-163$ & 6 & 156,0 & 25 & 11 & 46 \\
3 & $164-178$ & 6 & 171,0 & 25 & 17 & 71 \\
4 & $179-193$ & 5 & 186,0 & 21 & 22 & 92 \\
5 & $194-208$ & 0 & 201,0 & 0 & 22 & 92 \\
6 & $209-223$ & 2 & 216,0 & 8 & 24 & 100 \\
\hline Jumlah & & 18 & & 100 & & \\
\hline
\end{tabular}

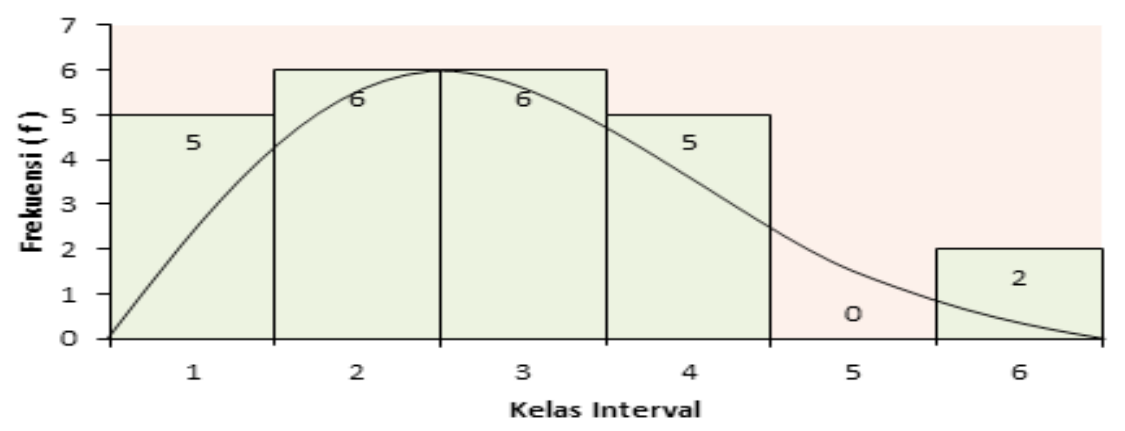

Gambar 8. Distribusi Frekuensi Skor Tiap Interval Pernyataan tentang Rumpun Kompetensi Penguasaan Bidang Studi 
Tabel 9. Distribusi Frekuensi tentang Rumpun Kompetensi Pemahaman Peserta Didik

\begin{tabular}{ccccccc}
\hline No Kelas & Kelas Interval & $\boldsymbol{f i}$ & $\boldsymbol{X i}$ & $\boldsymbol{f i}$ \% & $\boldsymbol{f i} \mathbf{~ k u m}$ & $\boldsymbol{f i}$ kum \% \\
\hline 1 & $139,0-155,3$ & 6 & 147,2 & 25 & 6 & 25 \\
2 & $155,4-171,7$ & 4 & 163,6 & 17 & 10 & 42 \\
3 & $171,8-188,1$ & 5 & 180,0 & 21 & 15 & 63 \\
4 & $188,2-204,5$ & 4 & 196,4 & 17 & 19 & 79 \\
5 & $204,6-220,9$ & 1 & 212,8 & 4 & 20 & 83 \\
6 & $221,0-237,3$ & 4 & 229,2 & 17 & 24 & 100 \\
\hline Jumlah & & 18 & & 100 & &
\end{tabular}

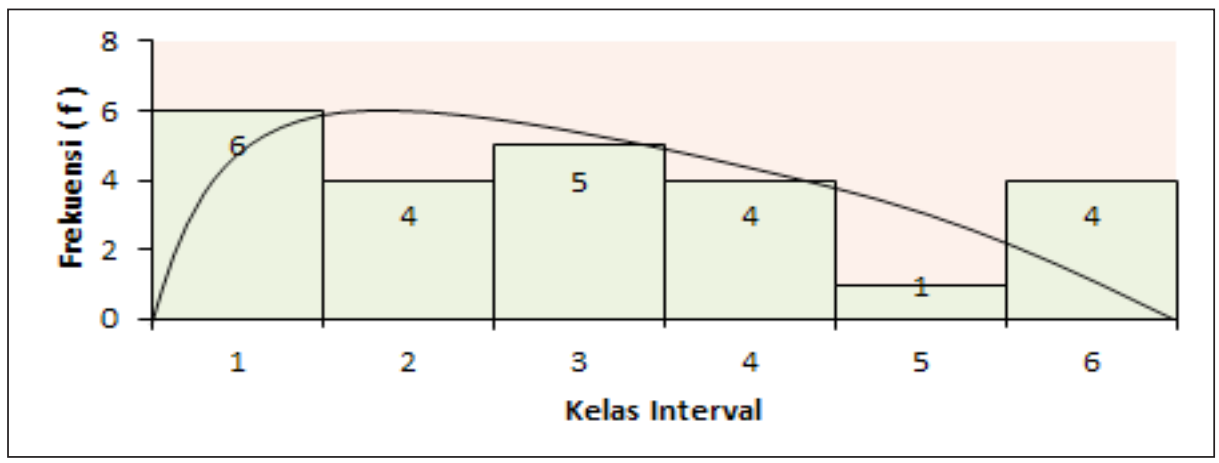

Gambar 9.Distribusi Frekuensi Skor Tiap Interval Pernyataan tentang Kompetensi Pemahaman Tentang Peserta Didik

Berdasarkan kajian secara kuantitatif, relevansi kompetensi penguasaan bidang studi pendidikan teknik mesin yang dimiliki Mahasiswa Program Studi PTM FKIP UNPAR yang sedang melaksanakan PPL II pada tahun ajaran 2012/2013, dengan standar kompetensi guru pemula SMK di Bidang Teknik Mesin termasuk dalam kategori relevan dengan nilai $64,23 \%$. Ditinjau dari seluruh aspek profil rumpun kompetensi penguasaan bidang studi pendidikan teknik mesin, kondisinya masih di bawah rerata dengan $\mathrm{Me} 167,87>\mathrm{Md}$ $165,28>$ Mo 163,95 dan koevisien variasi data 0,1263 . Melalui hasil kajian kualitatif dapat dijelaskan bahwa Mahasiswa PPL II belum memiliki kompetensi penguasaan bidang studi secara utuh sebagai calon guru pemula SMK, di mana selama pelaksanaan praktik mengajar mahasiswa PPL II lebih memilih untuk mengajar dikelas teori dan menghindari untuk terlibat dan berperan sebagai instruktur dalam kegiatan praktik kejuruan di SMK.

\section{Kompetensi Pemahaman Peserta Didik}

Rumpun kompetensi pemahaman peserta didik yang dapat dilihat pada tabel 9 meliputi tujuh aspek dengan jumlah butir pernyataan sebanyak 29 butir, skor ideal tiap responden 290, dan skor ideal untuk rumpun kompetensi pemahaman tentang peserta didik 6.960. Dari deskripsi data tersebut diketahui bahwa skor total yang diperoleh untuk aspek kompetensi pemahaman tentang peserta didik yaitu 4.356 , di mana skor untuk tiap responden yang terbesar adalah 237 dan terkecil adalah 139.

Berdasarkan kajian secara kuantitatif, relevansi kompetensi pemahaman peserta didik di SMK yang dimiliki Mahasiswa Program Studi PTM FKIP UNPAR yang sedang melaksanakan PPL II pada tahun ajaran 2012/2013, dengan standar kompetensi guru pemula SMK termasuk dalam kategori relevan dengan nilai $62,59 \%$. Ditinjau dari seluruh aspek profil rumpun kompetensi pemahaman tentang peserta didik di SMK, kondisinya masih di bawah rerata dengan Me 181,32>Md $179,80>$ Mo 166,28 dan koevisien variasi data 0,1565 . Melalui hasil kajian kualitatif dapat dijelaskan bahwa mahasiswa PPL II Belum mampu menciptakan atsmosfer belajar yang kondusif dalam proses pembelajaran di 
Tabel 10. Distribusi Frekuensi tentang Rumpun Kompetensi Penguasaan Pembelajaran yang Mendidik

\begin{tabular}{ccccccc}
\hline No Kelas & Kelas Interval & $\boldsymbol{f i}$ & $\boldsymbol{X i}$ & $\boldsymbol{f i} \mathbf{\%}$ & $\boldsymbol{f i} \mathbf{~ k u m}$ & $\boldsymbol{f i} \mathbf{~ k u m} \%$ \\
\hline 1 & $82-105$ & 1 & 93,5 & 4 & 1 & 4 \\
2 & $106-129$ & 1 & 117,5 & 4 & 2 & 8 \\
3 & $130-153$ & 2 & 141,5 & 8 & 4 & 17 \\
4 & $154-177$ & 13 & 165,5 & 54 & 17 & 71 \\
5 & $178-201$ & 3 & 189,5 & 13 & 20 & 83 \\
6 & $202-225$ & 4 & 213,5 & 17 & 24 & 100 \\
\hline
\end{tabular}

Jumlah $18 \quad 100$

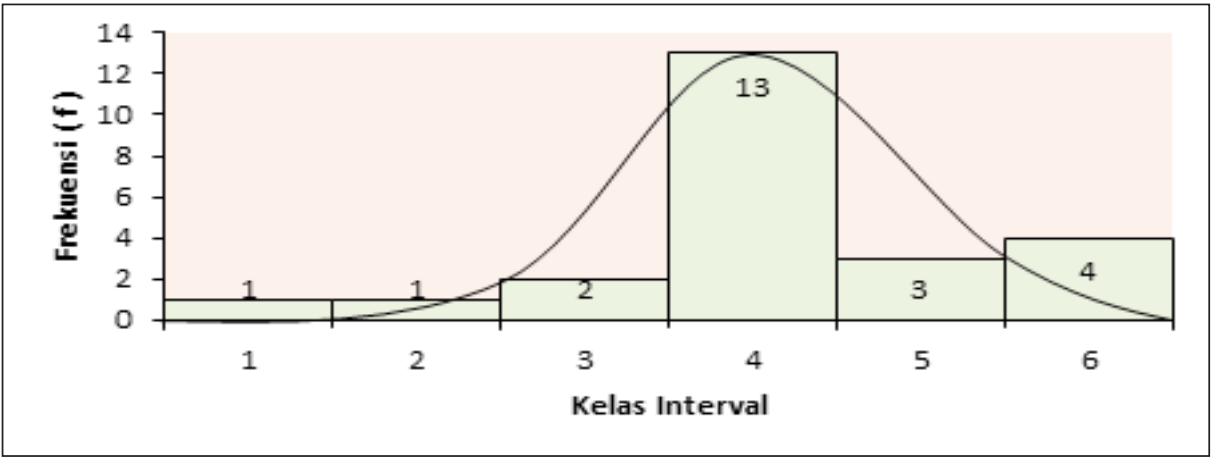

Gambar 10. Distribusi Frekuensi Skor Tiap Interval Pernyataan tentang Kompetensi Penguasaan Pembelajaran yang Mendidik

SMK, di mana selama proses mengajar lebih memfokuskan diri pada terselesaikannya materi yang diajarkan.

\section{Kompetensi Penguasaan Pembelajaran yang Mendidik}

Rumpun kompetensi penguasaan pembelajaran yang mendidik yang dapat dilihat pada tabel 10 meliputi tujuh aspek dengan jumlah butir pernyataan sebanyak 29 butir, skor ideal tiap responden 290, dan skor ideal untuk rumpun kompetensi penguasaan pembelajaran yang mendidik 6.960. Dari deskripsi data tersebut diketahui bahwa skor total yang diperoleh untuk aspek kompetensi penguasaan pembelajaran yang mendidik yaitu 4.116 , di mana skor untuk tiap responden yang terbesar adalah 224 dan terkecil adalah 82 .

Berdasarkan kajian secara kuantitatif, relevansi kompetensi penguasaan pembelajaran yang mendidik di SMK yang dimiliki Mahasiswa Program Studi PTM FKIP UNPAR yang sedang melaksanakan PPL II pada tahun ajaran 2012/2013, dengan standar kompetensi guru pemula SMK termasuk dalam kategori cukup relevan dengan nilai 59,14\%. Ditinjau dari seluruh aspek profil rumpun kompetensi penguasaan pembelajaran yang mendidik, kondisinya masih di bawah rerata. kondisinya masih di bawah rerata dengan Me 169,50>Md $168,10>$ Mo 166,52 dan koevisien variasi data 0,1669. Melalui hasil kajian kualitatif dapat dijelaskan bahwa mahasiswa PPL II belum mampu melaksanakan pembelajaran sesuai prinsip-prinsip dasar pembelajaran yang mendidik, di mana selama pelaksanaan praktik mengajar belum mampu menciptakan situasi belajar yang kreatif, aktif dan menyenangkan, memberi ruang yang luas bagi anak untuk dapat mengeksplor potensi dan kemampuannya sehingga dapat dilatih dan dikembangkan.

\section{Kompetensi Pengembangan Kepribadian dan Keprofesionalan}

Rumpun kompetensi pengembangan kepribadian dan keprofesionalan yang dapat dilihat pada tabel 11 meliputi tujuh aspek dengan jumlah butir pernyataan sebanyak 34 butir, skor ideal tiap responden 340, dan skor ideal untuk rumpun kompetensi pengembangan kepriba- 
Tabel 11. Distribusi Frekuensi tentang Rumpun Kompetensi

Pengembangan Kepribadian dan Keprofesionalan

\begin{tabular}{ccccccc}
\hline No Kelas & Kelas Interval & $\boldsymbol{f i}$ & $\boldsymbol{X i}$ & $\boldsymbol{f i} \%$ & $\boldsymbol{f i} \mathbf{~ k u m}$ & $\boldsymbol{f i} \mathbf{~ k u m} \%$ \\
\hline 1 & $184-201$ & 5 & 192.5 & 20,83 & 5 & 20,83 \\
2 & $202-219$ & 5 & 210.5 & 20,83 & 10 & 41,67 \\
3 & $220-237$ & 4 & 228.5 & 16,67 & 14 & 58,33 \\
4 & $238-255$ & 5 & 246.5 & 20,83 & 19 & 79,17 \\
5 & $256-273$ & 1 & 264.5 & 4,17 & 20 & 83,33 \\
6 & $274-291$ & 4 & 282.5 & 16,67 & 24 & 100 \\
\hline Jumlah & & 18 & & 100 & & \\
\hline
\end{tabular}

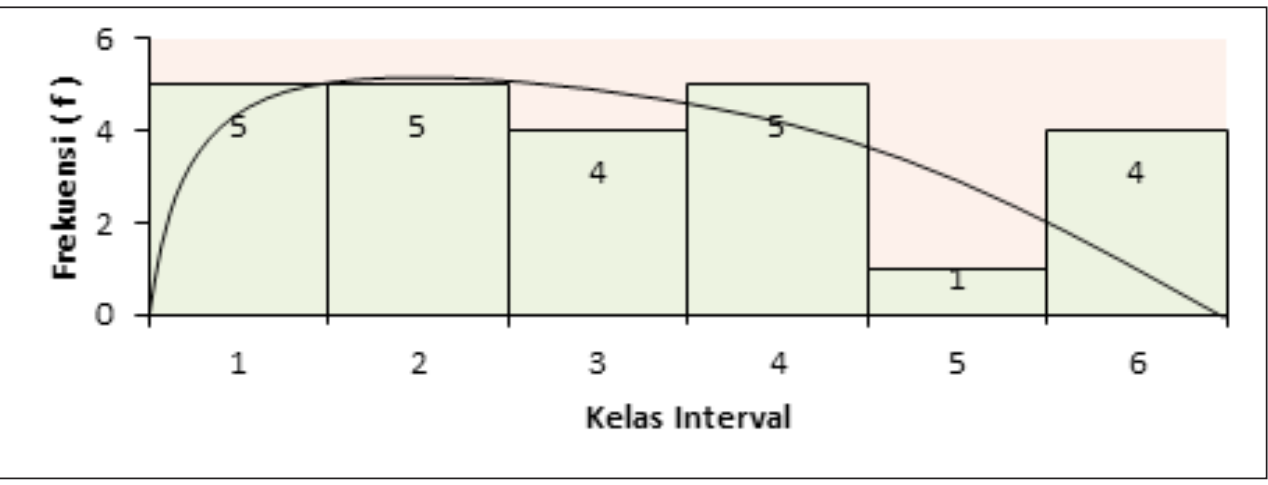

Gambar 11. Distribusi Frekuensi Skor Tiap Interval Pernyataan tentang Kompetensi Pengembangan Kepribadian dan Keprofesionalan

dian dan keprofesionalan 8.160. Dari deskripsi data tersebut diketahui bahwa skor total yang diperoleh untuk aspek kompetensi pengembangan kepribadian dan keprofesionalan yaitu 5.544, di mana skor untuk tiap responden yang terbesar adalah 290 dan terkecil adalah 184.

Berdasarkan kajian secara kuantitatif, relevansi kompetensi pengembangan kepribadian dan keprofesionalan yang dimiliki Mahasiswa Program Studi PTM FKIP UNPAR yang sedang melaksanakan PPL II pada tahun ajaran 2012/2013, dengan standar kompetensi guru pemula SMK, termasuk dalam kategori relevan dengan nilai $67,94 \%$. ditinjau dari seluruh aspeknya profil rumpun kompetensi pengembangan kepribadian dan keprofesionalan, kondisinya sudah di atas rerata dan rata-rata sudah berada di atas titik tengah. dengan $\mathrm{Md}$ $231,15<$ Me 231,50<Mo 241,55 dan koevisien variasi data 0,1322 . Melalui hasil kajian kualitatif dapat dijelaskan bahwa mahasiswa PPL II mampu menunjukkan sejumlah kompetensi yang berhubungan dengan kemampuan pribadi dengan segala karakteristik yang mendukung pelaksanaan tugas praktik mengajar, namun belum mampu melakukan refleksi terhadap kinerjanya.

\section{SIMPULAN DAN SARAN}

\section{Simpulan}

1. Relevansi kurikulum Program Studi PTM FKIP UNPAR dengan kebutuhan kompetensi guru pemula SMK Bidang Teknik Mesin termasuk dalam kategori relevan dengan persentase $72,96 \%$. Ditinjau dari profil kurikulum berdasarkan seluruh komponen kurikulum, kondisinya masih di bawah rerata, dengan relevansi tiap komponen kurikulum yaitu; komponen tujuan relevan dengan persentase $73,38 \%$, komponen isi/materi relevan dengan persentase $73,81 \%$, komponen prasarana sarana relevan dengan persentase $61,78 \%$, komponen proses relevan dengan persentase $74,97 \%$, komponen evaluasi relevan dengan persentase $75,51 \%$. 
2. Relevansi kompetensi yang dimiliki Mahasiswa Program Studi PTM FKIP UNPAR yang sedang melaksanakan PPL II pada tahun ajaran 2012/2013, dengan kompetensi guru pemula SMK termasuk dalam kategori relevan dengan persentase $63,64 \%$. Ditinjau dari profil seluruh rumpun kompetensi guru pemula SMK, kondisinya masih di bawah rerata, dengan relevansi tiap rumpun kompetensi yaitu; kompetensi penguasaan bidang studi relevan dengan persentase $64,23 \%$, kompetensi pemahaman peserta didik relevan dengan persentase $62,59 \%$, kompetensipenguasaan pembelajaran yang mendidik cukup relevan dengan persentase $59,14 \%$, kompetensi pengembangan kepribadian dan keprofesionalan relevan dengan persentase $67,94 \%$.

3. Program Studi PTM FKIP UNPAR menyelenggarakan dua konsentrasi bidang keahlian yaitu konsentrasi bidang mesin produksi dan konsentrasi bidang otomotif. Pada dokumen SKL Program Studi PTM FKIP UNPAR terdapat SKL konsentrasi bidang mesin produksi, namun belum terdapat SKL untuk konsentrasi bidang otomotif. Terdapat empat pola hubungan antara materi kajian pada kurikulum Program Studi FKIP UNPAR dengan SKGP SMK, yaitu: satu matakuliah bertujuan untuk mencapai beberapa kompetensi, satu kompetensi dibentuk melalui beberapa matakuliah yang berbeda, beberapa matakuliah yang berbeda memiliki keterkaitan untuk membentuk beberapa kompetensi, dan satu matakuliah bertujuan untuk membentuk satu kompetensi. Pada kurikulum Program Studi FKIP UNPAR terdapat 6 matakuliah konsentrasi bidang mesin produksi dan 6 matakuliah konsentrasi bidang otomotif yang tujuan pencapaian kompetensinya tidak terkait langsung dengan SKGP SMK. Indikator kompetensi SKGP SMK yang tidak masuk dalam rangkain materi kurikulum Program Studi PTM FKIP UNPAR bidang keahlian mesin produksi sebanyak 2 indikator kompetensi dan bidang keahlian otomotif sebanyak 4 indikator kompetensi. Program Studi PTM FKIP UNPAR belum menyelenggarakan sistem penjaminan mutu program studi. Fasilitas sumber belajar utama dan sarana pendukung kegiatan praktikum kondisinya masih kurang memadai untuk mendukung proses pendidikan dan pelatihan di Program Studi PTM FKIP UNPAR. Tenaga pengajar pada konsentrasi bidang otomotif jumlahnya belum memadai untuk mendukung pelaksanaan perkuliahan. Program Studi PTM FKIP UNPAR belum menerapkan pendekatan student centered learning pada proses pendidikannya. Evaluasi masih berfokus pada penilaian hasil belajar mahasiswa, sementara evaluasi terhadap proses belum dilakukan. Evaluasi kurikulum masih bersifat insidental, dan belum dilakukan kajian secara mendalam berdasarkan kebutuhan kompetensi lulusan (need assesment).

4. Mahasiswa PPL II mampu menampilkan kepribadian yang baik sebagai seorang calon guru pemula SMK; mampu menyusun program pembelajaran sesuai dengan tingkat perkembangan siswa, dan memilih materi sesuai dengan alokasi waktu bidang studi yang diampunya; mampu menggunakan teknologi informasi untuk mengembangkan pengetahuannya dan untuk mencari sumber-sumber baru dalam bidang studi pendidikan teknik mesin; belum memiliki kompetensi penguasaan bidang studi secara utuh sebagai calon guru pemula SMK, belum mampu berperan sebagai instruktur dalam pelaksanaan pembelajaran praktikum kejuruan di SMK; belum mampu menciptakan atsmosfer belajar yang kondusif dalam proses pembelajaran di SMK; belum mampu melaksanakan pembelajaran sesuai prinsip-prinsip dasar pembelajaran yang mendidik; dan belum mampu melakukan refleksi terhadap kinerjanya dalam proses pembelajaran.

\section{Saran}

Berdasarkan hasil penelitian yang telah disimpulkan di atas dan dalam upaya meningkatkan mutu penyelenggaraan program studi pendidikan teknik mesin FKIP UNPAR, dikemukakan beberapa saran sebagai berikut:

1. Penetapan visi misi serta tujuan dan sasaran program studi hendaknya dilakukan 
dengan melibatkan seluruh stakeholders yang ada, sehingga penetapan tujuan program studi mencerminkan kebutuhan para pemangku kepentingan di masyarakat (stakeholders).

2. Penetapan standar kompetensi lulusan hendaknya dilakukan melalui proses analisis kebutuhan kompetensi. Analisis kebutuhan dilakukan dengan mempertimbangkan aturan normatif yang berlaku, standar-standar yang ada seperti SKGP SMK dan SKKNI, dan informasi kebutuhan kompetensi dari stakeholders. Sehingga standar kompetensi lulusan yang ditetapkan betul-betul merupakan sederetan kompetensi yang dibutuhkan bagi calon guru pemula SMK di program studi pendidikan teknik mesin FKIP UNPAR.

3. Penetapan matakuliah hendaknya dilakukan melalui proses analisis terhadap materi kajian sesuai kompetensi yang dibutuhkan oleh mahasiswa calon guru pemula SMK di program studi pendidikan teknik mesin FKIP UNPAR. Analisis dilakukan dengan mempertimbangkan kandungan kompetensi yang terdapat dalam setiap materi kajian sehingga ditetapkan sebagai matakuliah sesuai dengan karakteristik kompetensi yang terkandung dalam materi kajian.

4. Penetapan struktur materi kurikulum persemester hendaknya ditetapkan dengan mempertimbangkan skuensi kompetensi yang terkandung dalam setiap matakuliah. Pertimbangan tersebut dapat dilakukan dengan meninjau apakah kandungan kompetensi yang terdapat pada suatu matakuliah merupakan kompetensi yang mendukung untuk penguasaan kompetensi selanjutnya, ataukah merupakan kompetensi yang bersifat paralel. Sehingga dapat membantu mempermudah mahasiswa dalam proses pencapain kompetensinya.

5. Kurang optimalnya sarana praktikum, sumber referensi, dan tenaga pengajar untuk bidang keahlian otomotif hendaknya segera dicari solusinya. Untuk mengatasi minimnya sarana praktikum dapat dilakukan melalui perencanaan dan pengadaan sarana bila memungkinkan. Alternatif lainnya yaitu dengan menjalin hubungan kerjasama dengan institusi lain. Hubungan kerja sama dilakukan dengan mempertimbangkan ketersediaan dan kelayakan sarana praktikum, serta ketersediaan dan kelayakan sumberdaya manusianya. Untuk mengatasi kurangnya referensi dapat dilakukan dengan perencanaan dan pengadaan referensi terkait. Solusi lainnya yaitu dengan mengadakan fasilitas TIK (internet), dan memanfaatkannya secara maksimal sebagai pemenuhan informasi sumbersumber belajar. Sementara untuk mengatasi kurangnya tenaga pengajar dapat dilakukan dengan perekrutan dosen tidak tetap, atau bekerja sama dengan institusi lain yang memiliki sumber daya manusia sesuai dengan kompetensi yang dibutuhkan.

6. Pendekatan pembelajaran yang digunakan masih bersifat teacher centered. Untuk meningkatkan kualitas pembelajaran, hendaknya program studi PTM FKIP UNPARmengadakanperubahanparadigma menuju pendekatan pembelajaran yang bersifat student centered. Dalam hal ini, para dosen perlu mengembangkan kemampuannya untuk memahami dan menerapkan berbagai model pembelajaran sesuai dengan karakteristik kompetensi yang akan dicapai.

7. Program studi PTM FKIP UNPAR hendaknya membentuk tim penjamin mutu dan menyelenggarakan penjaminan mutu program studi. Melalui tim penjamin mutu dapat ditetapkan standar mutu penyelenggaraan program studi. Tim penjamin mutu memiliki peranan untuk melakukan kegiatan perencanaan, pengawasan, dan evaluasi terhadap mutu penyelenggaraan program studi. Kegiatan penjaminan mutu penyelenggaraan program studi hendaknya dilakukan secara berkesinambungan. 


\section{DAFTAR PUSTAKA}

Beane, J.A., et.al, (1986). Curriculum Planning and Development. Newton, MA: Allyn and Bacon, Inc.

Creswell, J.W. \& Plano Clark, V.L. (2011). Designing and Conducting mixed methods Research 2Nd Edition, California: SAGE Publication.

Depdiknas. (2000). Keputusan Menteri Pendidikan Nasional RI Nomor 232, Tahun 2000, tentang Pedoman Penyusunan Kurikulum Pendidikan Tinggi Dan Penilaian Hasil Belajar Mahasiswa.

.(2002). Keputusan Menteri Pendidikan Nasional RI Nomor 045, Tahun 2002, tentang Kurikulum Inti Pendidikan Tinggi.

.(2003). Undang-Undang Republik Indonesia Nomor 20, Tahun 2003, tentang Sistem Pendidikan Nasional.

.(2005). Peraturan Pemerintah Republik Indonesia Nomor 19, Tahun 2005, tentang Standar Nasional Pendidikan

(2005). Undang-Undang Republik Indonesia Nomor 14, Tahun 2005, tentang Guru dan Dosen.

.(2007). Peraturan Menteri Pendidikan Nasional Republik Indonesia Nomor 16, Tahun 2007, tentang Standar Kualifikasi Akademik dan Kompetensi Guru

. (2010). Peraturan Menteri Pendidikan Nasional Republik Indonesia Nomor 27, Tahun 2010, tentang Program Induksi Bagi Guru Pemula

Depnaker, (2003) Undang Undang Republik Indonesia Nomor 13, Tahun 2003, tentang Ketenagakerjaan.

Devore, P.W. (1980). Technology an Introduction. Worcester, Massaachusetts, United States of America. Davis Publications, Inc.
Dirjen Dikti. (2004). Standar Kompetensi Guru Pemula Sekolah Menengah Kejuruan. Jakarta: Direktorat Jenderal Pendidikan Tinggi.

.(2008). Buku Panduan Pengembangan Kurikulum Berbasis Kompetensi Pendidikan Tinggi (Sebuah alternatif penyusunan kurikulum). Jakarta, Direktorat Jenderal Pendidikan Tinggi.

.(2010). Sistem Penjaminan Mutu Perguruan Tinggi (SPM-PT). Jakarta, Direktorat Jenderal Pendidikan Tinggi.

European Union Programme For Croatia. (2008). Project: Implementation of New Curricula (service contract), Compendium of VET schools projects fi nanced under IPA Component IV grant scheme Implementation of New Curricula. Zagreb. Agency for Vocational Education and Training and Adult Education. Diakses tanggal 27 Desember 2012, dari http:// www.asoo.hr/UserDocsImages/projekti/ inovacije/Compendium.pdf

Gibson, K.L. \& Mitchell, L.M. (2005) Critical curriculum components in programs for young gifted learners. International Education Journal, Shannon Research Press, 6(2), 164-169.

Piskurich, G.M. (2006). Rapid Instructional Design Learning ID Fast And Right Second Edition. San Francisco. Pfeiffer, John Wiley \& Sons, Inc.

Project Management Institute. (2001) Project Manager Competency Development (PMCD) Framework. Newtown Square, Pennsylvania USA. Four Campus Boulevard, Project Management Institute, Inc.

Winecoff, H.L. (1989). Curriculum Development and Instructional Planning. Jakarta: Depdikbud. 